\title{
Angiotensin II Formation in the Intact Human Heart Predominance of the Angiotensin-converting Enzyme Pathway
}

\author{
Lawrence S. Zisman, ${ }^{*}$ William T. Abraham, ${ }^{*}$ Glenn E. Meixell, ${ }^{*}$ Brian N. Vamvakias, ${ }^{\ddagger}$ Robert A. Quaife, ${ }^{*}$ Brain D. Lowes, ${ }^{*}$ \\ Robert L. Roden, * Stephanie J. Peacock, * Bertron M. Groves, * Mary V. Raynolds, * Michael R. Bristow, * \\ and M. Benjamin Perryman* \\ * Department of Medicine, Division of Cardiology, B-139, University of Colorado Health Sciences Center, Denver, Colorado 80262, and \\ ${ }^{\ddagger}$ Golden Pharmaceuticals, Golden, Colorado 80401
}

\begin{abstract}
It has been proposed that the contribution of myocardial tissue angiotensin converting enzyme (ACE) to angiotensin II (Ang II) formation in the human heart is low compared with non-ACE pathways. However, little is known about the actual in vivo contribution of these pathways to Ang II formation in the human heart. To examine angiotensin II formation in the intact human heart, we administered intracoronary ${ }^{123}$ I-labeled angiotensin I (Ang I) with and without intracoronary enalaprilat to orthotopic heart transplant recipients. The fractional conversion of Ang I to Ang II, calculated after separation of angiotensin peptides by HPLC, was $0.415 \pm 0.104(n=5$, mean \pm SD $)$. Enalaprilat reduced fractional conversion by $89 \%$, to a value of $0.044 \pm 0.053(n=4$, $P=0.002)$. In a separate study of explanted hearts, a newly developed in vitro Ang II-forming assay was used to examine cardiac tissue $\mathrm{ACE}$ activity independent of circulating components. ACE activity in solubilized left ventricular membrane preparations from failing hearts was $49.6 \pm 5.3$ fmol ${ }^{125}$ I-Ang II formed per minute per milligram of protein $(n=8, \pm S E$ ), and $35.9 \pm 4.8 \mathrm{fmol} / \mathrm{min} / \mathrm{mg}$ from nonfailing human hearts $(n=7, P=0.08)$. In the presence of $1 \mu M$ enalaprilat, ACE activity was reduced by $85 \%$, to $7.3 \pm 1.4$ $\mathrm{fmol} / \mathrm{min} / \mathrm{mg}$ in the failing group and to $4.6 \pm 1.3 \mathrm{fmol} / \mathrm{min} /$ $m$ in the nonfailing group $(P<0.001)$. We conclude that the predominant pathway for angiotensin II formation in the human heart is through ACE. (J. Clin. Invest. 1995. 95:1490-1498.) Key words: angiotensin $I \cdot$ angiotensin-con-
\end{abstract}

Portions of this work have appeared in abstract form (Zisman, L.S., E. Bush, C.S. Taft, M.R. Bristow, M.B. Perryman, and M.V. Raynolds. 1994. Increase in Angiotensin Converting Enzyme gene expression and activity in the failing human ventricle. Circulation. 90:I-578 [Abstr.]. and Zisman, L.S., W.T. Abraham, G.E. Meixell, B.N. Vamvakias, B.D. Lowes, R.L. Roden, R.A. Quaife, B.M. Groves, M.R. Bristow, and M.B Perryman. 1995. Angiotensin II formation in the Intact Human Heart: Predominance of the Angiotensin Converting Enzyme pathway. Accepted American College of Cardiology 44th Annual Scientific Session [Abstr.]).

Address correspondence to M. Benjamin Perryman, Ph.D., Division of Cardiology, B139, University of Colorado Health Sciences Center, 4200 E. Ninth Ave., Denver, CO 80262. Phone: 303-270-3259; FAX: 303-270-3261.

Received for publication 10 January 1995 and accepted in revised form 18 May 1995.

J. Clin. Invest.

(C) The American Society for Clinical Investigation, Inc.

0021-9738/95/09/1490/09\$2.00

Volume 96, September 1995, 1490-1498 verting enzyme inhibitors - cardiomyopathy • peptidyl dipeptidase $\mathbf{A} \cdot$ renin-angiotensin system

\section{Introduction}

The importance of the renin-angiotensin system (RAS) ${ }^{1}$ in the development and progression of heart failure has been demonstrated in several large, randomized, double-blind clinical trials of angiotensin converting enzyme inhibitors (ACE-Is). These trials have shown a survival benefit from ACE-I therapy in patients with both symptomatic and asymptomatic left ventricular dysfunction $(1,2)$. This survival benefit correlates with a significant improvement in indices of left ventricular cardiac function, including ejection fraction (3). The VHeft II trial demonstrated that the mortality reduction provided by ACE-I therapy was significantly greater than that of the non-ACE-I vasodilator combination of hydralazine/isosorbide dinitrate (4). Furthermore, in patients with hypertension and left ventricular (LV) hypertrophy, ACE-I therapy may promote regression of LV hypertrophy to a greater extent than other forms of antihypertensive therapy (5). These clinical studies suggest that angiotensin converting enzyme (ACE) plays an important role in the pathophysiology of myocardial failure and hypertrophy, and that, at the cardiac tissue level, this response may be independent of peripheral hemodynamics. However, little is known about ACE substrate metabolism in the intact human heart.

The two major peptide substrates for ACE are angiotensin I (Ang I) and bradykinin. ACE removes the two terminal amino acids from the decapeptide Ang I to yield the active octapeptide hormone angiotensin II (Ang II). Ang II regulates systemic blood pressure by several mechanisms, including receptor-mediated vasoconstriction, promotion of sodium resorption in the proximal tubule of the kidney, and stimulation of aldosterone secretion from the adrenal medulla. Bradykinin has vasodilatory and antiproliferative properties (6); ACE, by hydrolyzing bradykinin, renders it inactive. Thus, ACE promotes systemic vasoconstriction by producing Ang II and concurrently catabolizing bradykinin.

Recent studies in animal models, cultured cells, and human cardiac tissue have demonstrated that components of the RAS are functionally expressed in the myocardium $(7,8)$. These data suggest that locally produced Ang II may modulate cardiac function. The autocrine/paracrine effects of intracardiac Ang II

1. Abbreviations used in this appear: ACE, angiotensin converting enzyme; ACE-I, angiotensin converting enzyme inhibitor; Ang I, angiotensin I; Cs, coronary sinus; CSBF, coronary sinus blood flow; IC, intracoronary; IDC, idiopathic dilated cardiomyopathy; ISC, ischemic cardiomyopathy; LV, left ventricular; RAS, renin-angiotensin system. 
may be distinct from the effects of systemically produced Ang II; potential effects of locally produced Ang II include facilitation of sympathetic neurotransmission (9-11), positive or negative inotropic effects $(12,13)$, and direct mitogenic effects on cardiomyocytes $(14,15)$.

Currently, there is controversy regarding the major pathway for Ang II formation in the human heart. Although ACE has been shown to mediate $70 \%$ of Ang I to Ang II conversion in isolated rat hearts, in vitro studies of the human heart have suggested that ACE mediates only $11 \%$ of Ang II formation $(16,17)$. Based on these in vitro studies, it has been proposed that the enzyme human heart chymase is primarily responsible for cardiac Ang II formation (18). However, the actual in vivo contribution of ACE and non-ACE mediated pathways to Ang I metabolism in the human heart has not been studied. Accordingly, we developed a novel protocol to quantify the conversion of Ang I to Ang II across the myocardial circulation in human subjects and to determine the fraction of conversion mediated by ACE. This protocol incorporates the use of an intracoronary (IC) infusion of ${ }^{123} \mathrm{I}$-labeled Ang I with a sequential concomitant IC infusion of the ACE inhibitor enalaprilat. Comparison of Ang I to Ang II conversion with and without enalaprilat allows a calculation of the fractional conversion that is mediated in vivo by $\mathrm{ACE}$. Additionally, we developed an improved in vitro tissue ACE assay that permits quantitative measurement of human heart ACE activity independent of circulating RAS components and applied this assay, in a set of experiments separate from the in vivo Ang II formation protocol, to measure ACE activity in LV myocardium from eight failing and seven nonfailing explanted human hearts.

\section{Methods}

Reagents. Sodium iodide $\left({ }^{123} \mathrm{I}\right)$, sodium thiosulfate free, specific activity 32.3-61.1 $\mathrm{mCi} / \mathrm{ml}$ at the time of calibration, was obtained from Nordion International, Inc. (Vancouver, B.C., Canada). Angiotensin I for product synthesis was obtained from Sigma Chemical Co. (St. Louis, MO). Chloramine T was obtained from J. T. Baker Chemical Co. (Phillipsburg, NJ). Potassium hydroxide, sodium chloride, sodium phosphate (monobasic), glacial acetic acid, sodium hydroxide, sodium thiosulfate USP, HPLC grade methanol, and acetonitrile were obtained from Fisher Scientific (Pittsburgh, PA). Ang I, Ang II, and Ang III for standards, $85 \%$ orthophosphoric acid, triflouroacetic acid, bovine serum albumin (fraction V, RIA grade), Triton-X100, Hepes, potassium chloride, zinc sulfate, EDTA, 1,10-phenanthroline, trichloroacetic acid, deoxycholic acid, and sodium azide were obtained from Sigma Chemical Co. Enalaprilat was kindly provided by Merck Research Laboratories (West Point, PA). The renin inhibitor Ro 42-5892 was kindly provided by HoffmanLaRoche, Inc. (Nutley, NJ). Medium mesh P4 and AG1X8 resins were obtained from Bio-Rad Laboratories (Hercules, CA). 25\% HSA and sterile pyrogen free water were obtained from Baxter Healthcare Corporation (Deerfield, IL). ${ }^{125} \mathrm{I}$-labeled angiotensin I, ${ }^{125} \mathrm{I}$-labeled angiotensin II, and ${ }^{125} \mathrm{I}$-labeled angiotensin IV were obtained from New England Nuclear (Bedford, MA). ${ }^{3} \mathrm{H}$-Hipglygly was obtained from Hycor Biomedical, Inc. (Irvine CA).

Subjects, in vivo Ang II formation protocol. Five orthotopic heart transplant recipients with normal left ventricular function and coronary anatomy were recruited from the group of patients undergoing routine annual surveillance cardiac catheterization at the University of Colorado Health Sciences Center. All patients were on a standard regimen of cyclosporin (dose range 100-125 mg b.i.d.), azathioprine (Imuran; dose range 50-150 mg q.d.), and diltiazem (dose range 120-360 mg q.d.). Two patients were on aspirin $81 \mathrm{mg}$ q.d., and three patients were on furosemide (Lasix; dose range $20 \mathrm{mg}$ q.d. to $40 \mathrm{mg}$ b.i.d.). No patients were on ACE-I therapy for at least 12 mo before enrollment. Four patients were male, one was female. Ages ranged from 34 to $59 \mathrm{yr}$. Lugol's solution was administered starting the day before the study and was given for a total of $3 \mathrm{~d}$ to block thyroid uptake of ${ }^{123} \mathrm{I}$. This study was approved by the Colorado Multiple Institution Review Board, and written informed consent was obtained from all subjects before study.

${ }^{123}$ Iodination of Ang I. Iodination of Ang I was performed using the chloramine $\mathrm{T}$ method (19) and purified as described by Admiraal et al. (20) with slight modifications. All reagents were of USP grade or equivalent and prepared with sterile, pyrogen-free water. Glassware was depyrogenized by baking at $200^{\circ} \mathrm{C}$ for $12 \mathrm{~h}$. Plasticware and columns were depyrogenized with $1 \% \mathrm{KOH}$ and then autoclaved at $120^{\circ} \mathrm{C}$ for $45 \mathrm{~min}$. $1 \mathrm{mg}$ Ang I was reconstituted with $4 \mathrm{ml} 0.25 \mathrm{M} \mathrm{NaH}_{2} \mathrm{PO}_{4}, \mathrm{pH}$ 7.5. $20 \mu \mathrm{l}$ reconstituted Ang I was added to a $1.5-\mathrm{ml}$ polypropylene microcentrifuge tube containing $40 \mu \mathrm{l} 0.25 \mathrm{M} \mathrm{NaH}_{2} \mathrm{PO}_{4}, \mathrm{pH} 7.2,10 \mu \mathrm{l}$ $\mathrm{KI}\left(1 \mathrm{ng} / \mu \mathrm{l}\right.$ in $\left.0.25 \mathrm{M} \mathrm{NaH}_{2} \mathrm{PO}_{4}, \mathrm{pH} 7.4\right)$, and $10 \mu \mathrm{l}{ }^{123} \mathrm{I} .20 \mu \mathrm{l} 14$ $\mathrm{mM}$ chloramine $\mathrm{T}$ was added, and the reaction vessel vortexed for 20 s. To stop the reaction, $20 \mu \mathrm{l} 22 \mathrm{mM}$ sodium thiosulfate was added. Iodination was verified by thin layer chromatography. This reaction was repeated until a total of $10 \mathrm{mCi}^{123} \mathrm{I}$ activity was used. The reactions were pooled and loaded via a flow adaptor (Bio-Rad Laboratories) onto a $2.5 \times 10 \mathrm{~cm} \mathrm{AG1X8} \mathrm{column}$. Elution was carried out with $0.1 \mathrm{M}$ acetic acid containing $0.2 \%$ HSA to remove free ${ }^{123} \mathrm{I}$. Labeled product was diverted to a sterile $30 \mathrm{ml}$ vial and loaded by a peristaltic pump through a flow adaptor onto a $2.5 \times 50 \mathrm{~cm} \mathrm{P4}$ column. The P4 resin was prepared in $0.05 \mathrm{M}$ acetic acid/0.1 M NaCl, pH 6.0, for autoclaving and equilibrated overnight with elution buffer ( $0.05 \mathrm{M}$ acetic acid/0.1 $\mathrm{M} \mathrm{NaCl} / 0.2 \% \mathrm{HSA}$ ). Product eluted from the column was collected in four fractions of $15,30,30$, and $15 \mathrm{ml}$ volume. The detection system consisted of a $\mathrm{NaI}$ scintillation detector, a photomultiplier tube, a single channel analyzer, an amplifier, and a quad counter/timer (EG\&G Ortec, Oak Ridge, TN). Calibration was performed using a ${ }^{137} \mathrm{Cs}$ source. The second fraction contained predominantly mono-iodinated Ang I (90\%) as verified by HPLC. This fraction was counted in an ion chamber (Capintec Inc., Ramsey, $\mathrm{NJ}$ ) to determine total activity. The $\mathrm{pH}$ was adjusted to 7.4 with $5 \% \mathrm{NaOH}$, and the fraction filtered through a 0.2 $\mu \mathrm{m}$ Acrodisc (Gelman Sciences, Inc., Ann Arbor MI). Before administration to the patients, an aliquot of this product was subjected to pyrogen testing (Limulus assay; Cape Cod Associates, Woods Hole, MA). In addition, sterility testing was performed (Infinity Laboratories, Inc., Littleton, CO).

Cardiac catheterization. Standard procedures for routine left and right heart catheterization were employed. Coronary sinus (CS) catheterization was performed via the right internal jugular vein using a $7 \mathrm{~F}$ Webster thermodilution catheter for blood sampling from the CS and for monitoring of coronary sinus blood flow (CSBF). Catheter position in the left coronary artery was confirmed by contrast injection before the initiation of the IC infusion of any study medication. The CS catheter position was confirmed by contrast injection and blood sampling for percentage of oxygen saturation. Delivery of the IC medications was controlled by an automatic infusion pump (Harvard Apparatus, North Reading, MA). A 5F JL4 catheter was used for infusion of the IC medications to allow simultaneous sampling from the femoral artery sheath and the CS. CSBF was measured using the standard technique of thermodilution as previously described (21). A timeline for the in vivo protocol is presented in Fig. 1.

After routine catheterization was completed, an IC infusion of Ang I was given for $5 \mathrm{~min}(0.01 \mu \mathrm{g} / \mathrm{min})$ to saturate nonspecific binding in the plastic tubing and catheters. An IC infusion of Ang I labeled with the radioisotope ${ }^{123} \mathrm{I}$ to a specific activity of $440-1,890 \mu \mathrm{Ci} / \mu \mathrm{g}$ at the time of administration was infused via the Judkins catheter into the left main coronary artery at $1 \mathrm{ml} / \mathrm{min}, 0.01-0.05 \mu \mathrm{g} / \mathrm{min}$. The infusion was given for a period of $6 \mathrm{~min}$, during which time blood sampling was performed at 3-min intervals from the femoral artery and the CS. During the first case, the infusion was given for a period of $12 \mathrm{~min}$ to determine time to steady state. Because there was no significant difference between the fractional Ang I-to-Ang II conversion at 6 versus $12 \mathrm{~min}$, subsequent infusion times were limited to $6 \mathrm{~min}$. A simultaneous IC infusion 


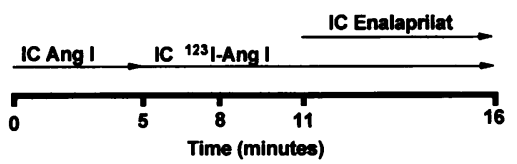

Figure 1. Timeline for the in vivo Ang II formation protocol. After a 5min infusion of unlabeled Ang I, an infusion of ${ }^{123}$ I-labeled Ang I

was administered into the left main coronary artery for $6 \mathrm{~min}$; a concomitant IC infusion of enalaprilat $(0.01 \mathrm{mg} / \mathrm{min})$ was then added for 5 min. Blood was sampled from the coronary sinus and femoral artery, and coronary sinus blood flow was measured at the indicated timepoints.

of enalaprilat at $0.01 \mathrm{mg} / \mathrm{min}$ was administered after $6 \mathrm{~min}$ of ${ }^{123} \mathrm{I}$ labeled Ang I infusion, and blood sampling was performed after 5 min of the combined infusion. CSBF measurements were performed at baseline and during the ${ }^{123} \mathrm{I}$-labeled Ang I and simultaneous ${ }^{123} \mathrm{I}$-labeled Ang I/enalaprilat infusion. The $0.01 \mathrm{mg} / \mathrm{min}$ dose of IC enalaprilat was chosen because higher doses (i.e., $0.05 \mathrm{mg} / \mathrm{min}$ ), which were previously reported to have no systemic hemodynamic effects (22), were found in some cases to lower systemic blood pressure (unpublished observations).

Dosimetry of ${ }^{123}$ I-labeled Ang I. 24-h urine collections were obtained in 8-h aliquots to quantify urinary excretion of ${ }^{123} \mathrm{I}$ activity. Thoracic and abdominal images were acquired with a scanner equipped with a general purpose, parallel-hole collimator (Body scan, Siemens Medical, Inc., Iselin, NJ). A $10 \%$ window centered on the $159 \mathrm{KeV}$ peak for ${ }^{123} \mathrm{I}$ was used, and the acquisition time was $10 \mathrm{~min}$. Scans and thyroid uptake studies were performed within $6 \mathrm{~h}$ of completion of the study protocol; thyroid uptake studies were repeated $24-48 \mathrm{~h}$ later to quantify ${ }^{123} \mathrm{I}$ uptake. The rate of urinary excretion of radioactivity was fit to an exponential decay function to yield an exponential elimination constant (INPLOT; GraphPad Software, Inc., San Diego, CA). This constant, the total administered activity, the fraction of activity eliminated in the urine, and the measured fraction of activity taken up by the thyroid were used to calculate time-activity curves (23). The residence times calculated for the total body, heart, and thyroid were used to calculate the dose to these compartments (MIRDOSE 2; Oak Ridge Institute for Science, Oak Ridge, TN).

Sample analysis. The combined HPLC/RIA method of Danser et al. (24) with slight modifications was used to separate and quantify unlabeled Ang I, Ang II, and Ang III, as well as iodinated Ang I and Ang II. Briefly, blood samples were immediately placed in inhibitor solution containing $0.01 \mathrm{mM}$ renin inhibitor (Ro 42-5892), $6.25 \mathrm{mM}$ EDTA, $1.25 \mathrm{mM}$ 1,10-phenanthroline, and $0.02 \mathrm{mM}$ enalaprilat (final concentration in blood). Plasma was extracted on C18 Sep-pak cartridges (Waters Chromatography, Bedford, MA) eluted with methanol, lyophilized, and reconstituted in mobile phase. HPLC was performed with a C18 Nucleosil column (Alltech Associates, Inc., Deerfield, IL). Mobile phase A consisted of $0.085 \%$ orthophosphoric acid $/ 0.02 \%$ sodium azide; mobile phase $B$ consisted of methanol. The gradient was isocratic with $\mathrm{A} 65 \%-\mathrm{B} 35 \%$ from 0-9 min followed by a gradient of mobile phase B to $55 \%$ over $9 \mathrm{~min}$ at $45^{\circ} \mathrm{C}$. Fractions were collected, neutralized to $\mathrm{pH} 7.4$, and counted in a gamma counter. After counting, the samples were lyophilized, reconstituted in RIA buffer, and fractions assayed for Ang I and Ang II. Ang II was measured using the Nichols Institute RIA Kit (San Juan Capistrano, CA); Ang I was measured using the RIA from Peninsula Laboratories (Belmont, CA). Retention times of Ang I, Ang II, and Ang III were determined using known standards and were $15.5,7.5$, and $5.8 \mathrm{~min}$, respectively. Retention times of ${ }^{123}$ I-labeled Ang I, ${ }^{123}$ I-labeled Ang II, and ${ }^{123}$ I-labeled Ang IV were determined using peptides labeled with ${ }^{125} \mathrm{I}$ and were $19,12.5$, and 15.5 $\mathrm{min}$. The activity of the samples resulting from the ${ }^{123} \mathrm{I}$ was allowed to decay to background levels before completion of the RIA.

Mathematical modeling. The venous equilibrium model used by Danser et al. (24) to study angiotensin metabolism across different vascular beds in pigs treats the intravascular space and the tissue com- partment as one well-stirred chamber. The mathematical arguments of this model have been previously described $(24,25)$. The fractional conversion of arterially delivered Ang I is defined as

$\mathbf{f}_{\mathrm{v}}=$ fractional conversion of Ang I to Ang II

$$
=E_{1} \times\left\{k_{2} t /\left(k_{1} t+k_{2} t\right)\right\},
$$

where $E_{1}$ is the extraction ratio of $A n g I, k_{2}$ is the first-order rate constant for conversion of Ang I to Ang II, and $k_{1}$ is the first-order rate constant for degradation of Ang I and Ang II to other metabolites including Ang III and Ang IV.

If the venous equilibrium model is correct, then the fractional conversion of ${ }^{123}$ I-labeled Ang I to ${ }^{123}$ I-labeled Ang II actually measured in samples taken from the CS should be the same as that predicted by Eq. 1. The fractional conversion of ${ }^{123} \mathrm{I}$-labeled Ang I to ${ }^{123} \mathrm{I}$-labeled Ang II measured in the CS is given by the following formula:

$\mathrm{f}_{\mathrm{m}}=\left({ }^{123} \operatorname{IAII}_{\mathrm{cs}}(\mathrm{cpm})\right) /\left({ }^{123} \operatorname{IAII}_{\mathrm{cS}}(\mathrm{cpm})+{ }^{123} \operatorname{IAI}_{\mathrm{cs}}(\mathrm{cpm})\right)$,

where ${ }^{123} \operatorname{IAII}_{\mathrm{cs}}(\mathrm{cpm})=$ counts per minute of ${ }^{123}$ I-labeled Ang II in the $\mathrm{CS}$, and ${ }^{123} \mathrm{IAI}_{\mathrm{cs}}(\mathrm{cpm})=$ counts per minute of ${ }^{123}$ I-labeled Ang $\mathrm{I}$ in the CS.

Under the condition $\mathrm{fv}>\mathrm{fm}$, there is net uptake of Ang II. In a simplified two-compartment model, this condition is accounted for by an effective uptake constant for Ang II:

$K_{\text {eff }}=\left\{f_{4}-f_{m}\right\} /\left\{f_{m}\left(1-f_{v}\right)\right\}$.

This relation is derived from the assumption that if one added back the counts derived from ${ }^{123}$ I-labeled Ang II that are taken up by the tissue compartment during passage through the myocardial vascular bed, then $f_{v}$ would equal

$$
\begin{aligned}
\mathrm{f}_{\mathrm{m}} *= & \left({ }^{123} \operatorname{IAII}_{\mathrm{cs}}(\mathrm{cpm})+\mathrm{K}_{\mathrm{eff}}\left\{{ }^{123} \operatorname{IAII}_{\mathrm{cs}}(\mathrm{cpm})\right\}\right) /\left(\operatorname{Total}_{\mathrm{cs}}(\mathrm{cpm})\right. \\
& \left.+\mathrm{K}_{\mathrm{eff}}\left({ }^{123} \operatorname{IAII}_{\mathrm{cs}}(\mathrm{cpm})\right\}\right) .
\end{aligned}
$$

Because this protocol requires determination of arteriovenous differences across the myocardial vascular bed, it is necessary to know the arterial input concentration of unlabeled Ang I and Ang II distal to the infusion site. The measured input concentration of Ang I infusion concentration is given by the following formula:

$(\mathrm{AI})_{\mathrm{lm}}=\left\{(\mathrm{AI})_{\mathrm{cath}} \times \mathrm{Q}_{\mathrm{cath}}\right\} / \mathrm{Q}_{\mathrm{cs}}+(\mathrm{AI})_{\mathrm{fa}}$

where $(\mathrm{AI})_{\mathrm{lm}}=$ Ang I concentration in the left main coronary artery distal to Ang I infusion site; $(\mathrm{AI})_{\text {cath }}=$ Ang I concentration in the infusion catheter; $(\mathrm{AI})_{\mathrm{fa}}=$ Ang I concentration in the femoral artery; $\mathrm{Q}_{\text {cath }}=$ infusion catheter flow rate; and $\mathrm{Q}_{\mathrm{cs}}=$ coronary sinus blood flow. Statistical analysis was performed with Statview $512+$ (BrainPower, Inc., Calabasas, CA). Unless otherwise noted, values are expressed as the mean $\pm S E$. For within-group comparisons, statistical significance was tested using the paired $t$ test; for between-group comparisons, the unpaired $t$ test was used.

In vitro cardiac tissue ACE assay: characteristics of assayed hearts. 16 human hearts obtained at the time of explantation were evaluated. The time from explanation to membrane preparation was less than 30 min, as routinely practiced in our laboratory. Eight of the explanted hearts were from patients with end-stage heart failure resulting from idiopathic dilated cardiomyopathy (IDC), and seven were from donors with normally functioning hearts that could not be placed for transplantation. One heart assayed at multiple substrate concentrations was from a patient with end-stage heart failure secondary to ischemic cardiomyopathy (ISC). The mean age of the IDC hearts and the nonfailing hearts was $43 \pm 5.5$ and $48 \pm 5.7$ years, respectively $(P=N S)$. The mean LV ejection fraction for the IDC hearts was $0.18 \pm 2.5$, the pulmonary capillary wedge pressure was $21.7 \pm 2.4 \mathrm{mmHg}$, and the mean cardiac index was $2.0 \pm 0.24 \mathrm{liter} / \mathrm{min} / \mathrm{m}^{2}$. Only IDC hearts from patients with documented evidence of hemodynamic compromise were used. Inclusion criteria were LV ejection fraction less than $35 \%$, and pulmonary capil- 
lary wedge pressure greater than $15 \mathrm{mmHg}$ or cardiac index less than 2.0 liter $/ \mathrm{min} / \mathrm{m}^{2}$. For the nonfailing hearts, in all cases, the LV ejection fraction was greater than $50 \%$. More detailed hemodynamic data for the donor hearts was unavailable; however, the $\beta_{1}$-adrenergic receptor density in the failing hearts was $34.7 \pm 4.1 \mathrm{fmol} / \mathrm{mg}$, whereas the $\beta_{1}$ adrenergic receptor density in the nonfailing hearts was $63.5 \pm 5.4 \mathrm{fmol} /$ $\mathrm{mg}(P=0.002)$. The use of $\beta_{1}$-adrenergic receptor density as a quantitative criterion for the classification of human myocardial tissue as failing versus nonfailing has been previously established by our laboratory (26). Such quantitation supplements standard hemodynamic variables for which only qualitative information is typically available for donor hearts. Of the eight IDC hearts assayed, five had been exposed to ACEIs during the preceding 6 mo and two had not received ACE-I therapy for a period of at least 3 mo before transplantation. The one ISC heart examined had a left ventricular ejection fraction of 0.11 and a history of prior long-term ACE-I exposure. All of the IDC patients were on regimens of digoxin, Lasix, and coumadin for a period of time exceeding 3 mo before transplantation. None were on aspirin. There was no prior history of ACE-I exposure in the nonfailing group, and no patients in this group were taking digoxin, diuretics, or aspirin.

Tissue ACE assay: sample analysis. A high-yield crude membrane preparation of ventricular myocardium was prepared as previously described (27). The membrane preparation was solubilized at $4^{\circ} \mathrm{C}$ in an equal volume of resuspension buffer $(0.01 \mathrm{M}$ Hepes, $0.3 \mathrm{M} \mathrm{KCl}, 0.6 \%$ Triton-X100, $\mathrm{pH} 7.5$ ) for $4 \mathrm{~h}$ and centrifuged at $25,000 \mathrm{~g}$ for $1 \mathrm{~h}$. The supernatant was dialyzed extensively against $0.01 \mathrm{M}$ Hepes, $\mathrm{pH} 8.1$, $0.3 \mathrm{M} \mathrm{KCl}, 0.02 \%$ Triton-X100, $100 \mu \mathrm{m} \mathrm{ZnSO}_{4}$ to remove the EGTA in the membrane preparation suspension buffer and ACE-I if present. This combination of solubilization and dialysis was derived from the method of Bull et al. (28). $100 \mu \mathrm{l}$ sample was diluted in $400 \mu \mathrm{l} \mathrm{ACE}$ buffer ( $0.05 \mathrm{M}$ Hepes, $\left.\mathrm{pH} 8.0,0.1 \% \mathrm{NaN}_{3}\right) .50 \mu$ of this dilution was incubated with $50 \mathrm{fmol}$ of the ACE substrate ${ }^{125} \mathrm{I}$-labeled Ang I for 20 min at $37^{\circ} \mathrm{C}$. The ${ }^{125} \mathrm{I}$-labeled Ang I was reconstituted in $2 \mathrm{ml} \mathrm{ACE}$ buffer I ( $0.05 \mathrm{M}$ Hepes, $0.1 \mathrm{M} \mathrm{NaCl}, 0.01 \%$ Triton-X100, $50 \mu \mathrm{M} \mathrm{ZnSO}_{4}$, $\mathrm{pH} 8.0$ ) and diluted to achieve a concentration of $1 \mathrm{fmol} / \mu \mathrm{l}$ in $0.05 \mathrm{M}$ Hepes, $0.1 \% \mathrm{NaN}_{3}, \mathrm{pH}$ 8.0. When performing assays to generate data for Lineweaver-Burk plots, four different concentrations of substrate were used: $25 \mathrm{fmol}, 50 \mathrm{fmol}, 75 \mathrm{fmol}$, and $150 \mathrm{fmol}$ per reaction. Appropriate dilutions of concentrated ${ }^{125}$ I-labeled Ang I were made to achieve this range of values. To inhibit ACE in these preparations, parallel samples were made with the addition of $1 \mu \mathrm{M}$ enalaprilat. Al samples were assayed in duplicate. The reaction was stopped with 300 $\mu \mathrm{l} 0.2 \%$ trifluoroacetic acid. $133 \mu \mathrm{l}$ acetonitrile was added and $200 \mu \mathrm{l}$ of the sample was chromatographed on an HPLC system using a Vydac 201HS54 column (Hesperia, CA). Mobile phase A was $0.2 \%$ trifluoroacetic acid in $\mathrm{H}_{2} \mathrm{O}$; mobile phase $\mathrm{B}$ was acetonitrile. The gradient was isocratic from 0 to $3 \mathrm{~min}$ with mobile phase B $25 \%$; from 3 to $12 \mathrm{~min}$ a gradient increased mobile phase $B$ to $40 \%$. The flow rate was $1.2 \mathrm{ml} /$ min, and the temperature $25^{\circ} \mathrm{C}$. Under these conditions, ${ }^{125} \mathrm{I}$-labeled Ang I eluted at $9.5 \mathrm{~min}$, whereas ${ }^{125} \mathrm{I}$-labeled Ang II eluted at $7 \mathrm{~min}$. Elution times were determined using known standards of ${ }^{125}$ I-labeled Ang I and ${ }^{125} \mathrm{I}$-labeled Ang II. 0.5-ml fractions were collected and counted in a gamma counter. ACE activity was calculated according to the following formula:

Units $(\mathrm{fmol} / \mathrm{min} / \mathrm{mg})=$ Total activity* (AII) $/\{(\mathrm{AI}) *$ s.a.* (sample volume $)($ time $)(\mathrm{mg} / \mathrm{ml})\}$ where $A I I={ }^{125}$ I-labeled Ang II activity, $\mathrm{AI}={ }^{125} \mathrm{I}$-labeled Ang I activity, and s.a. = specific activity of ${ }^{125} \mathrm{I}$ labeled Ang I at the time of sample analysis, which included correction for decay and counting efficiency; $\mathrm{mg} / \mathrm{ml}$ indicates the protein concentration.

When the ACE specific substrate ${ }^{3} \mathrm{H}$-Hipglygly was used in this assay, ACE activity was on the order of $5-10 \mathrm{nmol} / \mathrm{min} / \mathrm{mg}$ versus 20-30 nmol $/ \mathrm{min} / \mathrm{mg}$ in nonfailing versus failing hearts and was found to parallel ACE activity determined using ${ }^{125} \mathrm{I}$-labeled Ang I as the substrate.

Protein assay. BSA was reconstituted in dialysis buffer to a concentration of $1 \mathrm{mg} / \mathrm{ml}$. Total protein from 0 to $0.125 \mathrm{mg}$ was added to a total volume of $1 \mathrm{ml} \mathrm{H}_{2} \mathrm{O}$ in $0.025-\mathrm{mg}$ increments. 50 and $75 \mu \mathrm{l}$ of dialyzed samples were brought to a total volume of $1 \mathrm{ml}$ with $\mathrm{H}_{2} \mathrm{O}$. To the BSA standards and the samples, $100 \mu 10.15 \%$ deoxycholic acid was added followed by $100 \mu 172 \%$ TCA. After vortexing, the standards and samples were centrifuged at $2000 \mathrm{~g}$ for 15 minutes. The supernatant was discarded, and a Lowry assay was performed to quantify the precipitated proteins (29). Absorbance at $750 \mathrm{~nm}$ was measured with a microplate reader (Thermomax; Molecular Devices, Sunnyvale, CA).

Lineweaver-Burk plots. ACE activity in solubilized membrane preparations from three failing hearts and three nonfailing hearts was measured at four different substrate concentrations. The reciprocal of substrate concentration was plotted against the reciprocal of ACE activity. Linear regression was performed to determine the best fit of the data for each heart assayed (INPLOT; GraphPad Software, Inc., San Diego, CA). The $K_{m}$ and $V_{\max }$ were calculated for each heart as the negative reciprocal of the $\mathrm{x}$-intercept and the inverse of the $y$-intercept, respectively.

\section{Results}

Hemodynamics of patients enrolled in the in vivo Ang II formation protocol. The baseline heart rate of the five patients in the in vivo study was $74.8 \pm 6.9$ beats per minute. The mean systolic blood pressure was $131.2 \pm 13.4 \mathrm{mmHg}$, and the mean diastolic blood pressure was $83.2 \pm 9.4 \mathrm{mmHg}$. The mean $\mathrm{LV}$ end diastolic pressure for the five patients was $9.2 \pm 3.4 \mathrm{mmHg}$. The mean pulmonary capillary wedge pressure, cardiac index, and LV ejection fraction were $7.4 \pm 2.3 \mathrm{mmHg}, 2.92 \pm 0.38$ liters/ $\mathrm{min} / \mathrm{m}^{2}$, and $0.69 \pm 0.08$, respectively. The mean CSBF at baseline before the infusion of any study medication was $93.1 \pm 14.0$ $\mathrm{ml} / \mathrm{min}$. The mean CSBF after the 6-min IC infusion of ${ }^{123} \mathrm{I}-$ labeled Ang I was $106 \pm 8.0 \mathrm{ml} / \mathrm{min}$, and the mean CSBF after the 5-min combined IC ${ }^{123}$ I-labeled Ang I/enalaprt infusion was $106.1 \pm 7.43 \mathrm{ml} / \mathrm{min}$. In no case was a decrease in CSBF observed during the IC ${ }^{123} \mathrm{I}$-labeled Ang I infusion, nor did a significant change in CSBF occur during the IC enalaprilat infusion. Thus, appropriate to the design of this study, the doses of infused medications were in the subpharmacologic range.

Dosimetry of ${ }^{123}$ I-labeled Ang $I$. The total radioactivity administered to each patient was $274 \pm 41.7 \mu \mathrm{Ci}$. The percentage of urinary excretion of total administered activity at $24 \mathrm{~h}$ was $66.1 \pm 5.9 \%$, and the fraction of total activity taken up by the thyroid was $0.037 \pm 0.008$. The dose to the thyroid was $0.373 \pm 0.071 \mathrm{rad}$, to the heart, $0.987 \pm 0.145 \mathrm{rad}$, and the total body dose was $0.022 \pm 0.003 \mathrm{rad}$. The dose to the heart represents a maximum estimate because it was assumed that the residence time in the heart was the same as total body residence time. Fig. 2 demonstrates the distribution of ${ }^{123}$ I-labeled Ang Infused activity in images obtained $2 \mathrm{~h}$ after the study in one patient who did not receive intracoronary enalaprilat. A significant proportion of activity is retained in the heart. A small amount of activity can be appreciated in the region of the thyroid as well as the kidneys.

ACE-mediated Ang I conversion in the intact human heart. A measure of the fractional conversion of Ang I to Ang II across the myocardial vascular bed was obtained by taking the ratio of activity of the labeled Ang II to the sum of activity corresponding to labeled Ang I and Ang II after peptide extraction and separation by HPLC (activity ratio method). This method assumes that the ratio of activity in samples taken from the CS reflects the conversion that occurs in the tissue compartment. This assumption describes the venous equilibrium model and can be tested by comparing the results of the activity ratio method with the results obtained from combined HPLC/RIA of both labeled and unlabeled Ang I and Ang II (RIA method). 


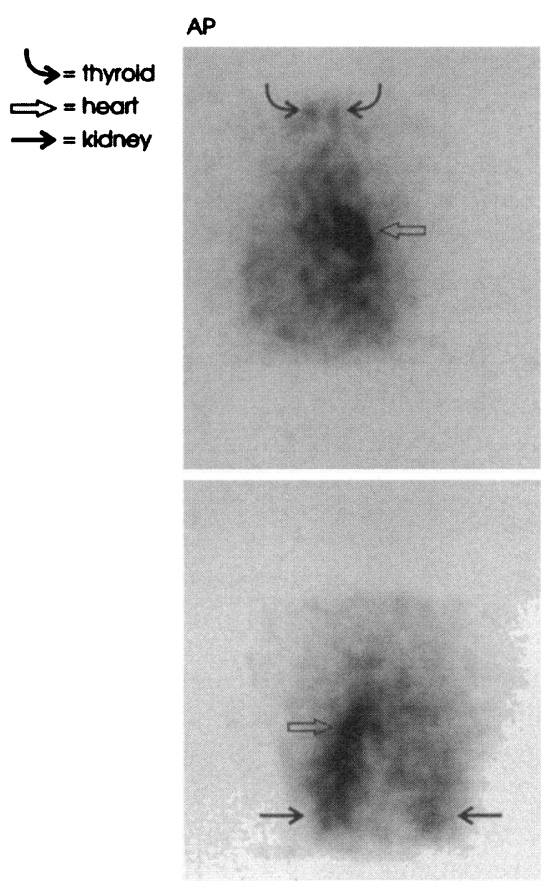

PA

Figure 2. Biodistribution of ${ }^{123} \mathrm{I}$-labeled Ang I $2 \mathrm{~h}$ after the in vivo study. A significant portion of activity is retained in the myocardium subtended by the left coronary artery system. A small amount of activity can be appreciated in the region of the thyroid and the kidneys. The top panel represents the anteroposterior (AP) view, and the bottom panel the posteroanterior (PA) view.

During the steady-state IC infusion of ${ }^{123}$ I-labeled Ang I, fractional conversion of Ang I to Ang II was 0.415 \pm 0.104 , and $0.430 \pm 0.158$ (mean $\pm S D)$ as determined, respectively, by the activity ratio and RIA methods $(n=5)$. Intracoronary enalaprilat $(0.01 \mathrm{mg} / \mathrm{min}$ for $5 \mathrm{~min})$ reduced fractional conversion by $89 \%$ to $0.044 \pm 0.053$ (activity ratio method) or $0.024 \pm 0.018$ (RIA method) $(n=4$, mean \pm SD, $P=0.002)$ (Fig. 3).

After 3 min of the ${ }^{123}$ I-labeled Ang I infusion, the calculated effective uptake constant for ${ }^{123}$ I-labeled Ang II was $0.79 \pm 0.38$, whereas the effective uptake constant for ${ }^{123}$ I-labeled Ang II at 6 min $0.232 \pm 0.361$. The first-order rate constant for degradation of labeled and unlabeled Ang I and Ang II to other metabolites

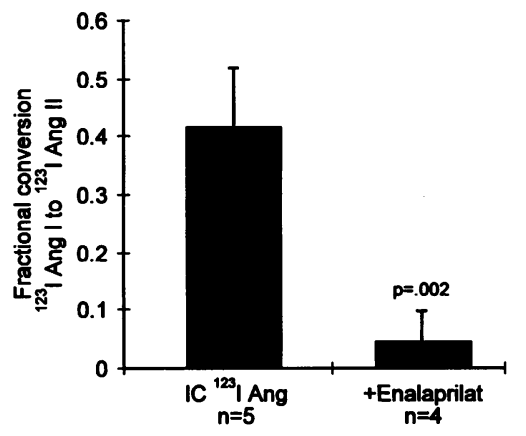

Figure 3. The fractional conversion of ${ }^{123} \mathrm{I}$-labeled Ang I to ${ }^{123}$-labeled Ang II across the intact human heart before and during concomitant administration of IC enalaprilat. During the steadystate IC infusion of ${ }^{123} \mathrm{I}-$ labeled Ang I, fractional conversion of ${ }^{123}$ I-labeled Ang I to ${ }^{123}$ I-labeled Ang II was $0.415 \pm 0.104$

(mean $\pm \mathrm{SD}, n=5$ ). IC enalaprilat reduced fractional conversion to $0.044 \pm 0.053$ ( $n=4$, mean $\pm \mathrm{SD}, P=0.002$ ), indicating that $89 \%$ of ${ }^{123}$ I-labeled Ang I conversion to ${ }^{123}$ I-labeled Ang II was mediated by ACE.

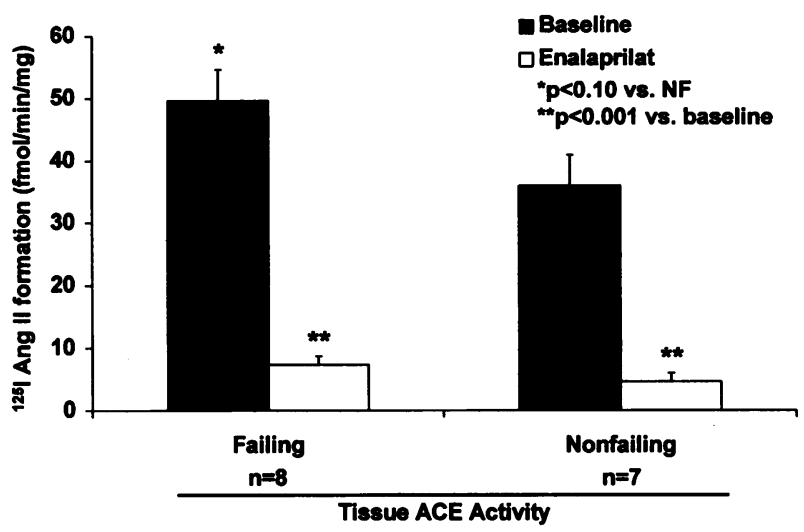

Figure 4. ACE activity in solubilized LV membranes prepared from explanted failing ( $n=8$, all IDC) and nonfailing ( $n=7)$ human hearts. Samples were incubated with ${ }^{125}$ I-labeled Ang I in the presence and absence of the ACE-I enalaprilat, and the formation of ${ }^{125} \mathrm{I}$-labeled Ang II was measured. $85 \%$ of ${ }^{125}$ I-labeled Ang II formation in vitro was mediated by ACE, and there was a trend toward higher ACE activity in the failing versus the nonfailing hearts.

was $0.137 \pm 0.034 \mathrm{~min}^{-1}$, and the first-order rate constant for conversion of labeled and unlabeled Ang I to Ang II was $0.163 \pm 0.048 \mathrm{~min}^{-1}$ at $6 \mathrm{~min}$. These data indicate mean net uptake of Ang II and a relative balance between Ang II formation and degradation at this 6-min time point. The extraction ratio of combined labeled and unlabeled Ang I was $0.794 \pm 0.048$, and the extraction ratio of combined labeled and unlabeled Ang II was $0.522 \pm 0.09$.

$A C E$ enzymatic activity in human myocardium. ACE activity in solubilized LV membrane preparations from failing hearts was $49.6 \pm 5.3 \mathrm{fmol}{ }^{125} \mathrm{I}$-labeled Ang II formed/per minute per milligram of protein ( $n=8$, all IDC), and $35.9 \pm 4.8 \mathrm{fmol} / \mathrm{min} /$ mig in LV preparations from nonfailing human hearts $(n=7$, $P=0.08$ failing vs. nonfailing). In the presence of $1 \mu \mathrm{M}$ enalaprilat, ACE activity in the failing group was reduced to $7.3 \pm 1.4 \mathrm{fmol} / \mathrm{min} / \mathrm{mg}$ and in the nonfailing group to $4.6 \pm 1.3$ $\mathrm{fmol} / \mathrm{min} / \mathrm{mg}$, a reduction of $85 \%(P<0.001)$ (Fig. 4). Tissue ACE activity in the two IDC hearts that had no prior history of ACE-I exposure ranged from 41.3 to $62.1 \mathrm{fmol} / \mathrm{min} / \mathrm{mg}$ with a mean of $51.7 \pm 6.9 \mathrm{fmol} / \mathrm{min} / \mathrm{mg}$.

Lineweaver-Burk plots were used to calculate the $\mathrm{K}_{\mathrm{m}}$ and $\mathrm{V}_{\max }$ for ACE in a small set of failing ( $n=3,2$ IDC, 1 ISC) and nonfailing $(n=3)$ human hearts. For the failing hearts, the $K_{m}$ was $223 \pm 57 \mathrm{fM}$ and for the nonfailing hearts, the $K_{m}$ was $255 \pm 65 \mathrm{f} \mathrm{M}(P=\mathrm{NS})$. The $\mathrm{V}_{\max }$ for the failing hearts was $391 \pm 65 \mathrm{fmol} / \mathrm{min} / \mathrm{mg}$, whereas the $V_{\max }$ for the nonfailing hearts was $298 \pm 66 \mathrm{fmol} / \mathrm{min} / \mathrm{mg}(P=\mathrm{NS})$ (Fig. 5).

\section{Discussion}

The major findings of this study may be summarized as follows: (1) conversion of Ang I to Ang II can be measured in the intact human heart; and (2) In a group of orthotopic heart transplant recipients with normal LV function, ACE mediated $89 \%$ of the conversion of Ang I to Ang II across the myocardial circulation in vivo. Furthermore, in a separate assay of solubilized human heart membrane preparations, ACE-mediated ${ }^{125}$ I-labeled Ang II formation was higher than previously reported and constituted $85 \%$ of total ${ }^{125}$ I-labeled Ang II formation. 


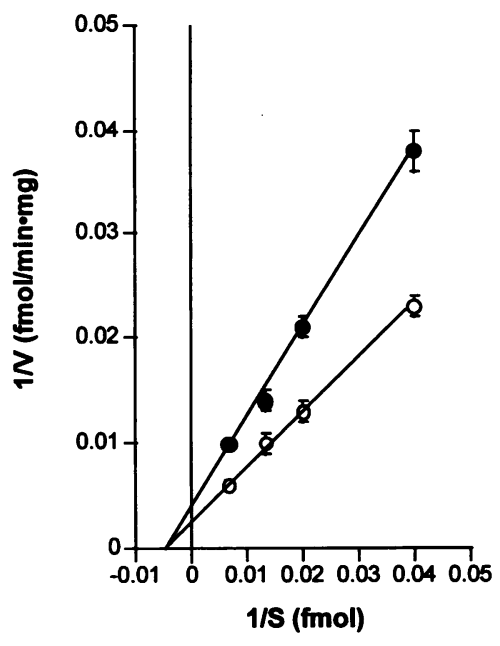

each heart assayed. The lower $y$-intercept for that the $\mathrm{V}_{\max }$ of ACE for this heart was higher than that for the nonfailing heart. For the failing hearts ( 2 IDC, 1 ISC), the $K_{m}$ was $223 \pm 57 \mathrm{fM}$; for the nonfailing hearts $(n=3)$, the $\mathrm{K}_{\mathrm{m}}$ was $255 \pm 65 \mathrm{fM}(P=\mathrm{NS})$. The $V_{\max }$ for the failing hearts, $391 \pm 65 \mathrm{fmol} / \mathrm{min} / \mathrm{mg}$, was $30 \%$ higher than the $V_{\max }$ for the nonfailing hearts, which was $298 \pm 66 \mathrm{fmol} / \mathrm{min} /$ $\mathrm{mg}(\mathrm{P}=\mathrm{NS})$.

The primary purpose of this study was to measure ACEand non-ACE-mediated Ang II formation in the intact human heart. In previously reported work in isolated rat hearts, ACE mediated $70 \%$ of the conversion of Ang I to Ang II (16). In pigs, in vivo ACE-mediated conversion of Ang I to Ang II across the heart was approximately $40 \%$ (24). However, based on the results of an in vitro tissue assay, it was shown that ACE mediated only $11 \%$ of Ang II formation in the human heart, and that the balance of Ang I-to-Ang II conversion was potentially mediated by human heart chymase $(17,30-32)$.

Studies of ${ }^{125}$ I-labeled Ang I metabolism have been performed across the renal, hepatic, and skeletal muscle vascular beds in humans $(20,33)$ as well as in pigs $(24,25)$. Prior studies of the acute effects of IC ACE-I administration in the intact human heart have also been undertaken and have demonstrated an effect on indices of cardiac function $(22,34)$. We have adapted these previously described methods specifically to study Ang II formation across the human myocardial circulation. The protocol that we have developed incorporates the use of an IC infusion of ${ }^{123} \mathrm{I}$-labeled Ang I with a sequential, concomitant IC infusion of the ACE-I enalaprilat. This protocol is unique in three ways: (1) because of concerns regarding dosimetry, we chose to use ${ }^{123} \mathrm{I}$-labeled Ang I rather that ${ }^{125} \mathrm{I}$-labeled Ang I; (2) to avoid potential systemic and pulmonary effects, we administered the labeled Ang I via the IC rather than the intravenous route (35); and (3) by using a dose of IC enalaprilat that was 10-50-fold lower than that used in other studies, we avoided potential confounding pharmacologic effects of this medication.

Using two different methods of sample analysis, the activity ratio method and the combined HPLC/RIA method, we calculated the fractional conversion of both labeled and unlabeled Ang I to Ang II across the heart. The combined HPLC/RIA method incorporates the fractional conversion term defined by the venous equilibrium model. Although both methods of analysis demonstrated that Ang II formation was primarily mediated by ACE, a simplified two-compartment model revealed evidence for net uptake of ${ }^{123}$ I-labeled Ang II. That the effective uptake constant for ${ }^{123}$-labeled Ang II was higher after $3 \mathrm{~min}$ compared with 6 min of the ${ }^{123}$ I-labeled Ang I infusion indicates an early distribution phase into the extravascular/tissue compartment before equilibrium. We chose to apply the venous equilibrium model to study Ang II formation in the heart because it had been applied with apparent success to the study of Ang I metabolism in other organs in human subjects (20). However, it is probably not an ideal model to describe the tissue distribution of angiotensin peptides in the human heart. Indeed, Dell'Italia et al. (36) reported that tissue Ang II levels in dog hearts may be higher than those measured in plasma, and Danser et al. (37) have presented data that suggest that tissue Ang II levels in pig hearts may be higher than would be predicted by the venous equilibrium model.

Because our in vivo protocol includes contributions of both membrane-bound and circulating ACE, we reexamined the importance of tissue ACE activity ex vivo. To develop an improved in vitro tissue ACE assay, we used dialysis to remove ACE-I, when present, from a solubilized human heart membrane preparation before incubation with substrate. This novel tissue ACE assay revealed that in vitro, $85 \%$ of ${ }^{125}$ I-labeled Ang II formation was mediated by ACE and therefore corroborated our in vivo data. In addition, there was a trend toward higher ACE activity in the failing hearts.

To explore further the regulation of cardiac tissue ACE activity in the failing heart, we determined the $K_{m}$ and $V_{\max }$ for ACE from Lineweaver-Burk plots. Measurement of these variables could reveal differences between non-failing and failing hearts that would be missed if the assay were performed at only one substrate concentration. Such differences, if present, might provide important clues about the regulation of tissue ACE in heart failure. For example, a lower $K_{m}$ in a failing heart would suggest that the affinity of ACE for substrate was increased compared with a nonfailing heart. In contrast, a significant increase in the $\mathrm{V}_{\max }$ of ACE in a failing heart would suggest either an increased ACE density in the membrane or an increased catalytic rate per molecule of enzyme. However, although the $\mathrm{V}_{\max }$ for ACE in the failing human hearts was $30 \%$ higher than that in the nonfailing human hearts studied over a range of substrate concentrations, this difference did not achieve statistical significance. Thus, additional experiments are required to determine if the secondary activation of the RAS precipitated by heart failure affects these variables in the human heart.

Both our in vivo and in vitro data indicate that $\mathrm{ACE}$ is the major Ang II-forming enzyme in the human heart. Several factors may contribute to the marked difference between our data and those Urata et al. (17). First, the on-off kinetics of captopril, the ACE-I used by Urata et al. (17) to inhibit ACE activity, may differ from those of enalaprilat; during the incubation of the membrane preparation with substrate, captopril may not be an effective in vitro ACE-I. The need to address this possibility has been raised by Kinoshita et al. (38). Second, the presence of nonsolubilized membrane may prevent access of ACE to substrate or in some other way inhibit the enzyme's in vitro activity. There is a precedent for the use of a solubilized membrane preparation to measure cardiac tissue ACE activity (39), and the assay for human heart chymase-like activity used a solubilized membrane preparation. Third, the $\mathrm{pH}$ of the membrane preparation used by Urata et al. (17), pH 7.1, may not 
have been optimized for ACE. Fourth, the membrane preparations used by this group were made from previously frozen tissue, whereas our preparations were made from freshly explanted hearts.

The crude membrane preparations used in our assay are enriched two- to threefold in $\beta$-adrenergic receptor binding relative to a washed pellet homogenate, indicating that this preparation is an enriched sarcolemmal fraction (26). However, the percentage of endothelial plasmalemma in this preparation is not known. Preparation of sheep cardiac sarcolemma according to the method of Jones et al. (40), which includes a contractile protein precipitation step as does our own, has been shown to enrich ACE activity compared with that of either a disrupted tissue or washed homogenate preparation. However, ACE activity determined from a sarcolemmal preparation of myocytes previously separated from endothelial cells on a sucrose gradient was lowered by a factor of 15 compared with whole heart (41). Based on these data, it was argued that the observed enrichment in ACE activity in the crude sarcolemmal preparation was secondary to the presence of endothelial plasmalemma. Whether or not the ACE activity we observed resulted from ACE solubilized from endothelial cell membranes and/or the sarcolemma is not known.

We found a trend toward increased cardiac tissue ACE activity in the failing IDC hearts compared with nonfailing hearts assayed in vitro. These data are consistent with both animal and human studies that have demonstrated an increase in ACE gene expression in failing hearts $(16,42-44)$. In failing human heart, ACE mRNA abundance was found to be threefold higher than in nonfailing heart (43). Chymase mRNA abundance in the same study was not different in failing versus nonfailing left ventricles, and, in a separate study, chymase activities in tissue extracts from nonfailing normal hearts or failing hearts (IDC and ISC) were not different (32).

Limitations. In our study, the majority of patients with heart failure in whom in vitro cardiac ACE activity was measured had at some time received ACE-I therapy. It is possible that the increase we observed in cardiac ACE activity in the failing heart was a secondary effect of this treatment rather than the result of regulatory mechanisms associated with myocardial failure or hypertrophy. The potential mechanism underlying such an effect could be induction of ACE expression through an as yet uncharacterized feedback loop triggered by chronic ACE inhibition. When ACE-Is are removed, as in our assay by dialysis, the functional effect of such increased expression would be revealed. Evidence for such a feedback mechanism has been found in lung ACE of rats treated with the ACE-I quinapril, and King and Oparil have clearly shown that ACE inhibition upregulates ACE mRNA and activity in both endothelial and neuronal cell cultures (45-47). However, Studer et al. (43) found no significant difference in cardiac ACE gene expression in patients treated with ACE-Is and patients not treated with ACE-Is. In addition, Wollert et al. (48) have demonstrated that, while LV ACE activity and ACE mRNa abundance were increased in rats with myocardial infarctions, longterm, high-dose ACE-I therapy did not alter cardiac tissue ACE activity. Furthermore, the relatively high cardiac ACE activities in the IDC hearts assayed in our study that had no prior history of ACE-I exposure suggest a primary role for chronic heart failure in the upregulation of cardiac tissue ACE. Nevertheless, given the evidence for ACE upregulation triggered by ACE-I treatment in cell culture, further studies of cardiac tissue not previously exposed to ACE-Is are essential to isolate the effect of heart failure.

Additional drug interactions may have affected both our measurements of in vivo Ang II formation and our in vitro tissue Ang II forming assay. Regarding our in vivo protocol, the patients for whom initial experience has been obtained were all orthotopic heart transplant recipients on a standard regimen of cyclosporin. Cyclosporin has been shown to increase an Ang II-mediated rise in intracellular calcium in rat vascular smooth muscle and mesangial cells $(49,50)$. Furthermore, cyclosporin has been shown to induce a twofold increase in gene expression of the angiotensin AT1A receptor in aortic endothelial cells (51). Thus, because cyclosporin affects the signal transduction pathway through which Ang II effects are at least in part mediated, we cannot exclude the possibility that this immunosuppressive agent alters Ang I metabolism. However, all of the patients studied in the in vivo protocol were also taking calcium channel blockers and were normotensive; it could therefore be argued that potential cyclosporin effects on the RAS mediated through changes in intracellular calcium were also interrupted.

Two of the five patients in whom in vivo cardiac Ang II formation was studied were on low-dose aspirin. Aspirin, a prostaglandin synthetase inhibitor, has been shown to attenuate angiotensin-mediated contraction of aortic muscle and Ang II sensitivity in a subset of pregnant patients $(52,53)$. Conversely, pretreatment with aspirin has been shown to reduce the vasodilatory effect of intraarterial enalaprilat in the forearm vascular bed (54). However, aspirin when combined with ACE-I therapy had no discernible effect on hemodynamic status in patients with heart failure (55). Although it is a tenable hypothesis that aspirin alters Ang II formation in the vascular beds of diverse organs, there was no observed difference in the relationship between ACE and non-ACE mediated Ang II formation in the intact hearts of the patients who were taking aspirin compared with those who were not (data not shown). Furthermore it should be kept in mind that our study of in vivo cardiac Ang II formation was not simply an examination of Ang I metabolism in the myocardial vascular bed. Conversion of I to Ang II was examined for the entire myocardial tissue compartment in equilibrium with the microvascular bed subtending the heart.

Regarding our in vitro assay, all of the IDC patients from whom cardiac tissue was obtained were on chronic diuretic therapy with furosemide. This diuretic has been shown to result in an increase in systemic Ang II levels (56). In addition, sodium balance has been shown to alter the hemodynamic response to the Ang II receptor antagonist saralasin (57). It is possible that altered volume status and sodium balance resulting from chronic diuretic therapy may contribute to the upregulation of ACE-mediated Ang II formation observed in the failing hearts studied.

Conclusion. The present study represents the first report of conversion of Ang I to Ang II in the intact human heart. This conversion may be mediated by both circulating and "tissue". specific or membrane-bound ACE. The relative contribution of circulating versus tissue-bound ACE to Ang II formation across the myocardial vascular bed cannot be determined from our in vivo protocol. However, it has been shown previously that the half-life of ${ }^{125}$ I-labeled Ang I in plasma ranges from 1.7 to 2.6 minutes (33). This half-life is an order of magnitude greater than the transit time across the human myocardial circulation (58) and therefore suggests that most of the conversion of Ang I to Ang II that we observed was mediated by tissue-bound 
ACE. Furthermore, the in vitro tissue ACE assay performed in the present study corroborates our findings in the intact human heart. We therefore conclude that the predominant pathway for Ang II formation in the human heart is through ACE. These results reinforce the clinical importance of ACE inhibitor therapy for the treatment of heart failure and provide support for the hypothesis that cardiac-specific ACE inhibitors will provide additional therapeutic benefit.

\section{Acknowledgments}

We are grateful for the invaluable assistance of the entire Cardiac Catheterization Laboratory nursing staff at University Hospital: Cathy Clark, R.N., Clare Conrardy, R.N., Kevin McShane, R.N., Karen Moore, R.N., Anne Oliva, R.N., Rhonda Olmsted, R.N., Lana Overturf, R.C.P.T., and Kim Trace, R.N., as well as Nina Leitman, C.N.M.T., and Michael R. Whitney, C.N.M.T., in the department of Nuclear Medicine. Tremendous gratitude is expressed to Frank Stewart and Jill Jones, who assisted in the preparation of the manuscript.

L. Zisman was supported by an American College of Cardiology/ Merck Fellowship. W. T. Abraham was supported by a Clinical Association Physician Award from the National Institutes of Health General Clinical Research Centers program.

\section{References}

1. Pfeffer, M. A., E. Braunwald, and the SOLVD Investigators. 1992. Effect of captopril on mortality and morbidity in patients with left ventricular dysfunction after myocardial infarction. N. Engl. J. Med. 327:669-677.

2. SOLVD Investigators. 1991. Effect of enalapril on survival in patients with reduced left ventricular ejection fractions and congestive heart failure. $N$. Engl. J. Med. 325:293-302.

3. Konstam, M. A., M. F. Rousseau, M. W. Kronenberg, J. E. Udelson, J. Melin, D. Stewart, N. Dolan, T. R. Edens, S. Ahn, D. Kinan et al. 1992. Effects of the angiotensin converting enzyme inhibitor enalapril on the long-term progression of left ventricular dysfunction in patients with heart failure. Circulation. 86:431-438.

4. Cohn, J. N., G. Johnson, S. Ziesche, F. Cobb, G. Francis, F. Tristani, R. Smith, B. Dunkman, H. Loeb, M. Wong et al. 1991. A comparison of enalapril with hydralazine-isosorbide dinitrate in the treatment of chronic congestive heart failure. N. Engl. J. Med. 325:303-310.

5. Dahlof, B., K. Pennert, and L. Hansson. 1992. Reversal of left ventricular hypertrophy in hypertensive patients: a metaanalysis of 109 treatment studies. Am. J. Hypertens. 5:95-110.

6. Stewart, J. 1989. Roles for kinins in inflammation. In Handbook of Inflammation, Vol. 6: Mediators of the Inflammatory Process. P. Henson, and R. Murphy, editors. Elsevier Science Publishing Co., New York. 189-217.

7. Dzau, V. J., and A. Hirsch. 1990. Emerging role of tissue renin-angiotensin systems in congestive heart failure. Eur. Heart J. 11:65-71.

8. Dzau, V. J. 1988. Circulating versus local renin-angiotensin system in cardiovascular homeostasis. Circulation. 77:4-13.

9. Hilgers, K., R. Veelken, G. Rupprecht, P. Reeh, F. Luft, and J. Mann. 1993. Angiotensin II facilitates sympathetic transmission in rat hind limb circulation. Hypertension. 21:322-328.

10. Gilbert, E. M., A. Sandoval, P. Larrabee, D. G. Renlund, J. B. O'Connell, and M. R. Bristow. 1993. Lisinopril lowers cardiac adrenergic drive and increases $\beta$-receptor density in the failing human heart. Circulation. 88:472-480.

11. Abraham, W. T., B. D. Lowes, C. P. Rose, P. Larrabee, and M. R. Bristow. 1994. Angiotensin II selectively increases cardiac adrenergic activity in patients with heart failure. J. Am. Coll. Cardiol. 23:215A.

12. Capasso, J. M., P. Li, X. Zhang, L. G. Meggs, and P. Anversa. 1993. Alterations in Ang II responsiveness in left and right myocardium after infarctioninduced heart failure in rats. Am. J. Physiol. 264:H2056-H2067.

13. Li, P., E. H. Sonnenblick, P. Anversa, and J. M. Capasso. 1994. Lengthdependent modulation of Ang II inotropism in rat myocardium: effects of myocardial infarction. Am. J. Physiol. 266:H779-H786.

14. Dzau, V., and R. Re. 1994. Tissue angiotensin system in cardiovascular medicine: a paradigm shift? Circulation. 89:493-498.

15. Sadoshima J.-I., Y. Xu, H. Slayter, and S. Izumo. 1993. Autocrine release of angiotensin II mediates stretch-induced hypertrophy of cardiac myocytes in vitro. Cell. 75:977-984.

16. Schunkert, H. B., S. S. Jackson, F. J. Tang, J. F. M. Schoen, C. S. Smits, B. H. Apstein, and B. H. Lorell. 1993. Distribution and functional significance of cardiac angiotensin converting enzyme in hypertrophied rat hearts. Circulation. 87:1328-1339.

17. Urata, H., B. Healy, R. W. Stewart, F. M. Bumpus, and A. Hussain. 1990 Angiotensin II-forming pathways in normal and failing human hearts. Circ. Res. 66:883-890.

18. Urata, H., A. Kinoshita, K. S. Misono, F. M. Bumpus, and A. Husain. 1990. Identification of a highly specific chymase as the major angiotensin IIforming enzyme in the human heart. J. Biol. Chem. 265:22348-22357.

19. Greenwood, F. C., W. M. Hunter, and J. S. Glover. 1963. The preparation of ${ }^{131} \mathrm{I}$ labeled human growth hormone of high specific radioactivity. Biochem. $J$. 89:114-123.

20. Admiraal, P. J. J., F. H. M. Derkx, A. H. Jan Danser, H. Pieterman, and A. D. H. Schalekamp. 1990. Metabolism and production of angiotensin I in different vascular beds in subjects with hypertension. Hypertension. 15:44-55.

21. Ganz, W., K. Tamura, and H. S. Marcus. 1971. Measurement of coronary sinus blood flow by continuous thermodilution in man. Circulation. 44:181-195.

22. Foult, J.-M., O. Tavolaro, I. Antony, and A. Nitenberg. 1988. Direct myocardial and coronary effects of enalaprilat in patients with dilated cardiomyopathy: assessment by a bilateral intracoronary infusion technique. Circulation. 77:337-344

23. Smith, T. 1988. A simplified recycling model for the dosimetry of radioiodide. Phys. Med. Biol. 33:1141-1157.

24. Danser, A. H. J., M. M. G. Koning, P. J. J. Admiraal, F. H. M. Derkx, P. D. Verdouw, and M. A. D. H. Schalekamp. 1992. Metabolism of angiotensin I by different tissues in the intact animal. Am. J. Physiol. 263:H418-H428.

25. Danser, A. H. J., M. M. G. Koning, P. J. J. Admiraal, L. M. A. Sassen, F. H. M. Derkx, P. D. Verdouw, and M. A. D. H. Schalekamp. 1992. Production of angiotensins I and II at tissue sites in intact pigs. Am. J. Physiol. 263:H429H437.

26. Bristow, M. R., R. Ginsburg, V. Umans, M. Fowler, W. Minobe, R. Rasmussen, P. Zera, R. Menlove, P. Shah, S. Jamieson, et al. 1986. $\beta 1$ - and $\beta 2$ adrenergic receptor subpopulations in nonfailing and failing human ventricular myocardium: coupling of both receptor subtypes to muscle contraction and selective $\beta 1$-receptor down-regulation in heart failure. Circ. Res. 59:297-309.

27. White, M., R. Roden, W. Minobe, M. F. Khan, P. Larrabee, M. Wollmering, J. D. Port, F. Anderson, D. Campbell, A. M. Feldman, et al. 1994. Age-related changes in $\beta$-adrenergic neuroeffector systems in the human heart. Circulation. 90:1225-1238.

28. Bull, H. G., N. A. Thornberry, and E. H. Cordes. 1985. Purification of angiotensin-converting enzyme from rabbit lung and human plasma by affinity chromatography. J. Biol. Chem. 260:2963-2972.

29. Lowry, O. H., N. J. Rosebrough, A. L. Farr, and R. J. Randall. 1951 Protein measurement with the Folin phenol reagent. J. Biol. Chem. 193:265-275.

30. Kinoshita, A., H. Urata, F. M. Bumpus, and A. Husain. 1991. Multiple determinants for the high substrate specificity of an angiotensin II-forming chymase from the human heart. J. Biol. Chem. 266:19192-19197.

31. Urata, H., A. Kinoshita, D. M. Perez, K. S. Misono, F. M. Bumpus, R. M. Graham, and A. Husain. 1991. Cloning of the gene and cDNA for human heart chymase. J. Biol. Chem. 266:17173-17179.

32. Urata, H., K. Boehm, A. Philip, A. Kinoshita, J. Gabrovsek, F. Bumpus, and A. Husain. 1993. Cellular localization and regional distribution of an angiotensin II-forming chymase in the heart. J. Clin. Invest. 91:1269-1281.

33. Admiraal, P. J. J., A. H. J. Danser, M. S. Jong, H. Pieterman, F. H. M Derkx, and M. A. D. H. Schalekamp. 1993. Regional angiotensin II production in essential hypertension and renal artery stenosis. Hypertension. 21:173-184.

34. Haber, H., E. Powers, L. Gimple, C. Wu, K. Subbiah, W. Johnson, and A. M. Feldman. 1994. Intracoronary angiotensin-converting enzyme inhibition improves diastolic function in patients with hypertensive left ventricular hypertrophy. Circulation. 89:2616-2625.

35. Magrini, F., P. Reggiani, M. Ciulla, R. Meazza, and G. Fratianni. 1992 Coronary haemodynamic effects of angiotensin II in mild essential hypertension in man. Clin. Sci. (Lond.). 82:133-137.

36. Dell'Italia, L. J., Q. C. Meng, I. Straeter-Knowlen, G. H. Hankes, S Bishop, S. Oparil, and T. Elton. 1994. Increased angiotensin peptide levels in cardiac tissue of dogs with chronic mitral regurgitation. Circulation. 90:I-451a. (Abstr.)

37. Danser, A. H. J., J. P. van Kats, P. J. J. Admiraal, F. H. M. Derkx, J. M. J. Lamers, P. D. Verdouw, P. R. Saxena, and M. A. D. H. Schalekamp. 1994 Cardiac renin and angiotensins: uptake from plasma versus in situ synthesis. Hypertension. 24;37-48.

38. Kinoshita, A., H. Urata, F. M. Bumpus, and A. Husain. 1993. Measurement of angiotensin I converting enzyme inhibition in the heart. Circ. Res. 73:51-60.

39. Grima, M., C. Welsch, E. Giesen-Crouse, C. Coquard, M. Barthelmebs, and J. Imbs. 1990. Age-related variations in tissue angiotensin converting enzyme activities: comparison between spontaneously hypertensive and Wistar-Kyoto rats. J. Hypertens. 8:697-702.

40. Jones, L. R., H. R. Besch, Jr., J. W. Fleming, M. M. McConnaughey, and A. M. Watanabe. 1979. Separation of vesicles of cardiac sarcolemma from vesicles of cardiac sarcoplasmic reticulum: comparative biochemical analysis of component activities. J. Biol. Chem. 254:530-539. 
41. Tomlins, B., S. E. Harding, M. S. Kirby, P. A. Poole-Wilson, and A. J. Williams. 1986. Contamination of a cardiac sarcolemmal preparation with endothelial plasma membrane. Biochim. Biophys. Acta. 856:137-143.

42. Hirsch, A., C. Talsness, H. Schunkert, M. Paul, and V. Dzau. 1991. Tissuespecific activation of cardiac angiotensin converting enzyme in experimental heart failure. Circ. Res. 69:475-482.

43. Studer, R., H. Reinecke, B. Muller, J. Holtz, H. Just, and H. Drexler 1994. Increased angiotensin-I converting enzyme gene expression in the failing human heart. J. Clin. Invest. 94:301-310.

44. Zisman, L. S., E. Bush, C. S. Taft, M. R. Bristow, M. B. Perryman, and M. V. Raynolds. 1994. Increase in angiotensin converting enzyme gene expression and activity in the failing human ventricle. Circulation. 90:I-578. (Abstr.)

45. Schunkert, H., J. R. Ingelfinger, A. T. Hirsch, Y. Pinto, W. J. Remme, H. Jacob, and V. J. Dzau. 1993. Feedback regulation of angiotensin converting enzyme activity and mRNA levels by angiotensin II. Circ. Res. 72:312-318.

46. King, S. J., and S. Oparil. 1992. Converting-enzyme inhibitors increase converting-enzyme mRNA and activity in endothelial cells. Am. J. Physiol. 263:C743-C749.

47. King, S. J., S. Oparil, and K. H. Berecek. 1991. Neuronal angiotensinconverting enzyme (ACE) gene expression is increased by converting enzyme inhibitors (CEI). Mol. Cell. Neurosci. 2:13-20.

48. Wollert, K. C., R. Studer, B. von Bulow, and H. Drexler. 1994. Survival after myocardial infarction in the rat: role of tissue angiotensin-converting enzyme inhibition. Circulation. 90:2457-2467.

49. Pfelischifter, J., and U. T. Ruegg. 1987. Cyclosporin A augments angiotensin II-stimulated rise in intracellular free calcium in vascular smooth muscle cells Biochem. J. 248:883-887.

50. Meyear-Lehnert, H., D. Bokemeyer, U. Friedrichs, S. Drechsler, and H. J.
Kramer. 1993. Cellular signaling by cyclosporine A in contractile cells: interactions with atrial natriuretic peptide. Clin. Invest. 71:153-60.

51. Iwai, J., Y. Kanayama, N. N. Inoue, M. Okamura, and T. Takeda. 1993. Increased endothelial gene expression of angiotensin AT1A receptor in cyclosporine induced hypertensive rats. Eur. J. Pharmacol. 248:341-344.

52. Altura, B. M., and B. T. Altura. 1976. Vascular smooth muscle and prostaglandins. Fed. Proc. 35:2360-2366.

53. Caruso, A., S. Ferrazzani, S. De Carolis, A. Lanzone, and S. Mancuso. 1991. Low-dose aspirin and vascular response in pregnant patients sensitive to angiotensin II. Int. J. Gynaecol. Obstet. 35:123-128.

54. Nakamura, M., T. Funakoshi, N. Arakawa, H. Yoshida, S. Makita, and K. Hiramori. 1994. Effect of angiotensin-converting enzyme inhibition on endothelium dependent peripheral vasodilation in patients with chronic heart failure. J. Am. Coll. Cardiol. 24: 1321-1327.

55. van Wijngaarden, J., A. J. Smit, P. A. de Graeff, W. H. van Gilst, S. A van der Broek, D. J. van Veldhuisen, K. I. Lie, and H. Wesseling. 1994. Effects of acetylsalicylic acid on peripheral hemodynamics in patients with chronic heart failure treated with angiotensin-converting enzyme inhibitors. J. Cardiovasc. Pharmacol. 23:240-245.

56. Semple, P. F. 1980. The effects of hemorrhage and sodium depletion on plasma concentrations of angiotensin II and [des-Asp 1] angiotensin II in the rat. Endocrinology. 107:771-773.

57. Cody, R. J., A. B. Covit, G. L. Schaer, and J. H. Laragh. 1984. Estimation of angiotensin II receptor activity in chronic congestive heart failure. Am. Heart J. 108:81-89.

58. Simon, R., M. Koch, G. H. Reil, G. Herrmann, I. Amende, W. Quante, and P. R. Lichtlen. 1988. Effects of intracoronary nitroglycerin on coronary vascular volume in man, assessed by a double-indicator dilution technique. Eur. Heart J. 9(Suppl. A):89-93. 